\title{
The Ussing chamber technique to evaluate alternatives to in-feed antibiotics for young pigs
}

\author{
Gaëlle BOUDRY* \\ Unité Mixte de Recherche Systèmes d'Élevage, Nutrition Animale et Humaine - INRA Agrocampus \\ Rennes, Domaine de la Prise, Saint-Gilles, France \\ (Received 4 May 2004; accepted 14 March 2005)
}

\begin{abstract}
The recent ban of in-feed antibiotics in animal production has brought scientists to find alternatives to in-feed antibiotics. The Ussing chamber is an in vitro technique in which intestinal tissue is collected and immediately mounted as a flat sheet between two half-chambers, establishing a luminal and a serosal side. This technique allows the measurement of actively transported ions as well as the permeability of the tissues, two parameters relevant for the evaluation of gut health. Ussing chambers have been used to describe the changes of intestinal physiology occurring at weaning. We observed that weaning induces an acute alteration of the epithelial barrier function and electrolyte transport in the first days. Long-lasting modifications (15 days after weaning) have also been observed. Alternatives to in-feed antibiotics can be evaluated by studying the intestinal physiology of animals treated with those alternatives. A benefic effect of pro- and pre-biotics on the rat intestine, human biopsies or epithelial cell monolayers has been demonstrated using Ussing chambers. In pigs, the influence of the source of dietary ingredients or the physical form of the diet seems limited. A few results obtained in pigs with pre- or probiotics appear less convincing than in laboratory animals. Another way to use Ussing chambers is to incubate the intestinal tissue with different substances added directly into the chambers. Some substances can be detrimental to the intestine, inducing electrolyte secretion or decreasing barrier function. However, some substances show a beneficial effect. Although this approach has limits and should be combined with in vivo measurements, it constitutes a rapid way to evaluate the effect of substances on intestinal physiology and can also, at least partly, elucidate the mechanisms of action of those alternatives.
\end{abstract}

weaning / piglets / intestinal physiology / Ussing chambers / alternatives to in-feed antibiotics

Résumé - Utilisation de la technique des chambres d'Ussing pour l'évaluation d'alternatives aux antibiotiques dans l'alimentation des porcelets. L'interdiction récente de l'utilisation d'antibiotiques dans l'alimentation animale a conduit les scientifiques à trouver des alternatives à ces pratiques d'élevage. La technique des chambres d'Ussing est une technique in vitro dans laquelle des sections d'intestin sont collectées et immédiatement montées entre deux demi-chambres, établissant ainsi un compartiment séreux et un compartiment muqueux. Ceci permet la mesure des transports actifs d'ions ainsi que de la perméabilité du tissu, deux paramètres intéressants dans l'évaluation de la santé du tube digestif. Les chambres d'Ussing ont été utilisées pour décrire les

\footnotetext{
* Corresponding author: Gaelle.Boudry@ rennes.inra.fr
} 
perturbations intestinales au moment du sevrage. Nous avons ainsi pu montrer que le sevrage induit des altérations transitoires de la physiologie intestinale ainsi que des modifications à plus long terme. Les alternatives aux antibiotiques peuvent être évaluées par l'étude de la physiologie intestinale des animaux traités avec ces alternatives. Un effet bénéfique des pro- et prébiotiques sur l'intestin de rat, des biopsies intestinales humaines ou des monocouches de cellules épithéliales intestinales a été démontré en chambres d'Ussing. Chez le Porc, l'influence des sources de matières premières ou de la forme physique de l'aliment semble limitée. De plus, les rares résultats obtenus chez le porc quant à l'effet des pré- et probiotiques semblent moins convaincants que chez les animaux de laboratoire. Une autre façon d'utiliser les chambres d'Ussing est d'incuber l'intestin avec différentes substances ajoutées directement dans les chambres. Certains composés semblent avoir un effet délétère sur l'intestin, induisant des sécrétions d'électrolytes ou des modifications de la barrière épithéliale. Cependant, certaines substances ont montré un effet bénéfique. Bien que cette technique ait des limites et doive être combinée à des expérimentations in vivo, elle constitue un moyen rapide d'évaluer l'effet de certains composés sur la physiologie intestinale tout en permettant d'élucider une partie des mécanismes mis en jeu.

sevrage / porcelet / physiologie intestinale / chambres d'Ussing / alternatives aux antibiotiques

\section{INTRODUCTION}

Antibiotics have been used in pig production for many years both as prophylactic agents and growth promoters. In order to avoid the appearance of antibio-resistance as well as to limit the presence of antibiotic residues in meat, the European Union has recently banned the use of in-feed antibiotics. The necessity of controlling animal gut health to preserve the competitivity of European pig production has brought scientists to evaluate alternatives to in-feed antibiotics. Rapidly, the necessity of using devices that allow evaluation of these alternatives in a simple and rapid way has arisen. Here, we propose to examine the use of an in vitro technique, the Ussing chamber, as such a device. So far, this technique has been underused in the evaluation of alternatives to in-feed antibiotics. The purpose of this review is therefore to present how this technique could be useful for the understanding of the mechanisms of actions of alternatives to in-feed antibiotics (pro- and pre-biotics, $\mathrm{Zn}$, various plant extracts...). The principle of the technique will be first presented, then the different uses of the technique illustrated: the use of Ussing chambers to (1) describe the disturbances of intestinal physiology at weaning, (2) evaluate the effect of alternatives to in-feed antibiotics applied in vivo and (3) test the effect of different substances added directly into the chambers.
This is not an exhaustive review and only few examples are given to illustrate the topics. The relevant examples are selected when possible from publications studying pigs. However, references to humans, rats, rabbits and even epithelial cell monolayers are also introduced.

\section{TECHNICAL ASPECTS}

\subsection{History of Ussing chambers}

The Ussing chamber device was named after its Danish inventor Hans H. Ussing (1911-2000). It was first designed to study vectorial ion transport through frog skin. Ussing's idea was simple: to short-circuit the frog skin. He would set the electrical potential difference (PD) across the frog skin to zero by applying an external current. If the concentration of an ion is the same on both sides of the epithelium and the PD is zero, and if there is no external force that can produce a net ion transport (i.e. the transport is passive), then the flux ratio is unity. On the contrary, if the ion is transported actively, the flux ratio is different from unity. Ussing and Zerahn used this principle to construct the Ussing chamber that later became so famous [41]. Nowadays, Ussing chambers have been adapted to study ion transport and permeability of epithelial tissues in laboratories throughout the world. 


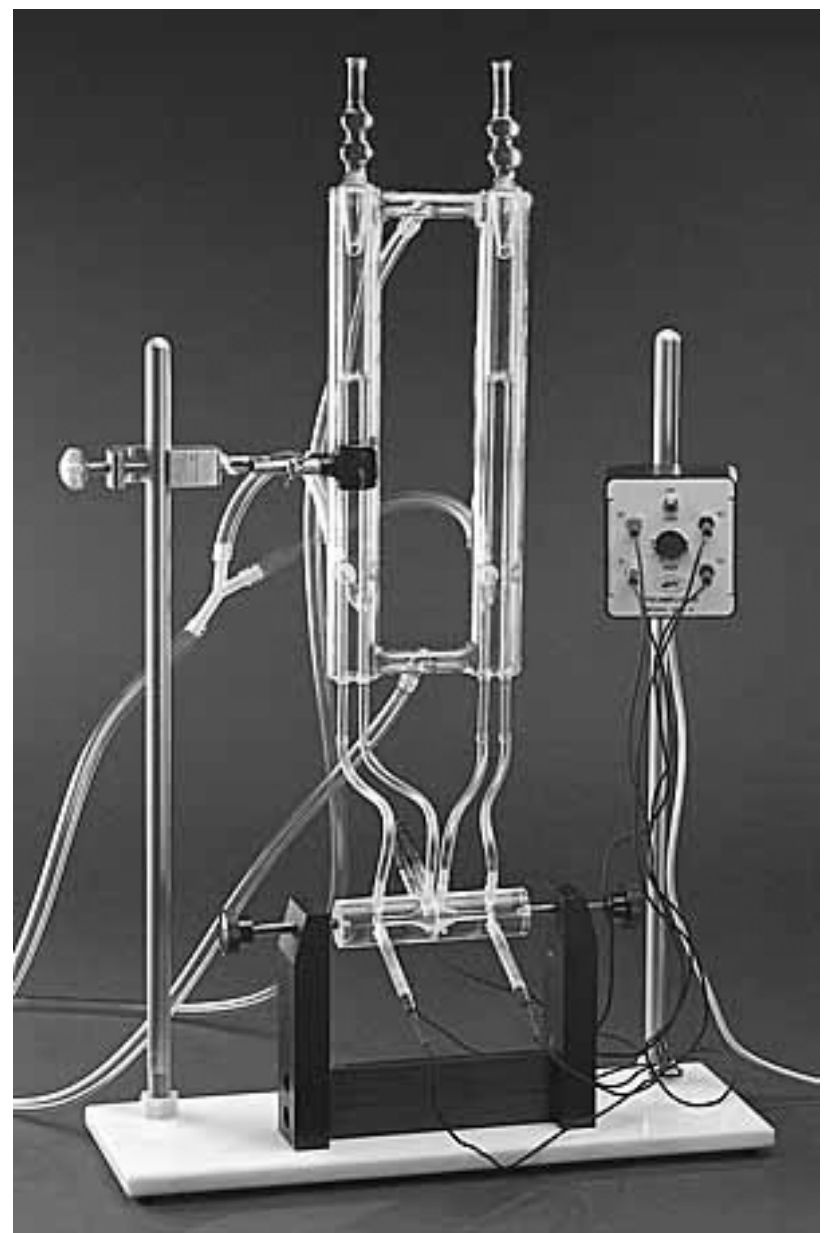

Figure 1. Picture of a circulating Ussing chamber; http://www.wpi-europe.com/tissuecell ussing system.html. The chamber is composed of two compartments, one mucosal and one serosal between which the intestinal mucosa is mounted as a flat sheet. A system of two sets of electrodes enables to short-circuit the tissue. A U-shaped reservoir, filled with warmed and oxygenated buffer, is connected to the compartments by a tubing system.

\subsection{Description of the device}

Two types of Ussing chambers can be found: the circulating chamber (Fig. 1) and the continuously perfused chamber (Fig. 2). In both cases, the tissue is collected and immediately mounted as a flat sheet between the two half-chambers, establishing a luminal and a serosal side. Electrodes are placed on both sides of the tissue to record the PD across the tissue. A set of two other electrodes allows the injection of a current (short-circuit current or Isc) to nullify the PD. The intensity of the current to be injected is monitored by an electric clamp apparatus. In the circulating chamber, a Ushaped tubing system filled with the experimental solution is connected to the chambers. A gas flow allows the oxygenation and stirring of the solutions. In the continuously 


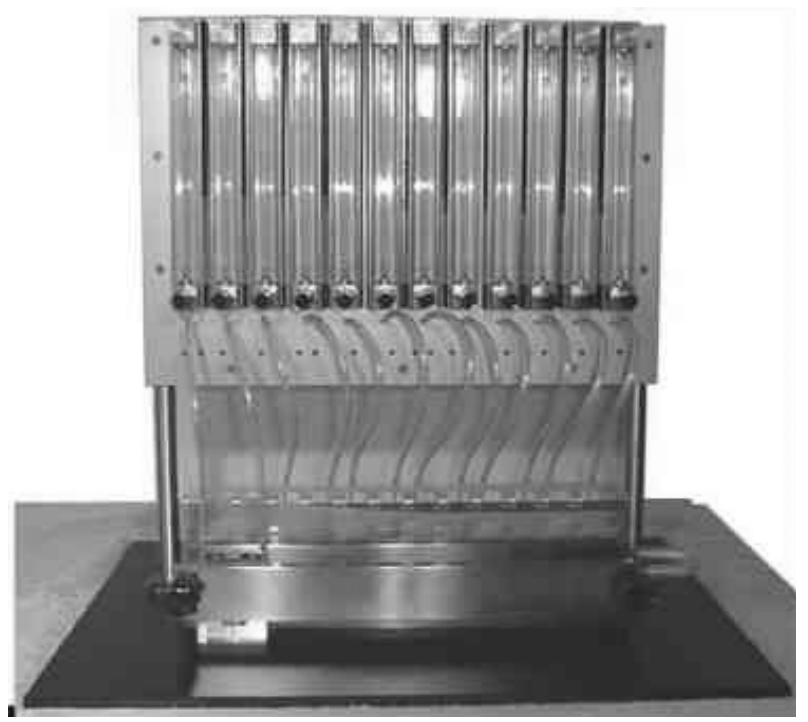

Figure 2. Picture of continuously perfused Ussing chambers, http://www.kmsci.de/Ussing/ ussing.html. The chambers are the same as in the circulating chambers. However, the buffer is continuously perfused to the chambers from reservoirs situated above the chambers.

perfused chamber, the solutions bathing the two sides of the tissue are delivered from reservoirs mounted $20-50 \mathrm{~cm}$ above the chambers via polyethylene tubes. Valves are used to regulate the flow rate. In both cases, temperature can be adjusted by means of a water jacket heating system.

\subsection{Type of experiments performed with Ussing chambers}

Ussing chambers allow the study of intestinal tissue for a couple of hours [38]. Different sites of the gastro-intestinal tract, from the stomach to the rectum, can be studied at the same time if the number of chambers available is adequate.

The original use of Ussing chambers with its clamp apparatus is to measure the transport of actively transported ions. In vivo, water follows the osmotic gradient created by actively transported ions [15]. Measuring Isc in Ussing chambers can therefore give indications on possible water movement in vivo and be useful to understand the pathophysiology of diarrhea $[16,21]$. This can be done at a basal level, without stimulation of the tissue, or after the addition in the chambers of pharmacological or natural substances inducing an active transport of ions (Fig. 3). Moreover, the study of Isc gives an indirect measure of electrolytedependent nutrient absorption such as glucose or amino-acids [19]. Lastly, the electrical device accompanying the Ussing chambers allows the measurement of the electrical resistance of the tissue $(\mathrm{R})$, or its inverse, the conductance $(G)$, considered to reflect the opening of the tight-junctions between epithelial cells, i.e. the paracellular permeability of the tissue.

The ability to maintain intestinal tissue alive in a controlled and an as-close-as-possible-to- physiological environment for a couple of hours has brought scientists to use this technique to study the permeability of intestinal tissue to various molecules, including ions [21], nutrients [1], drugs [25], small 


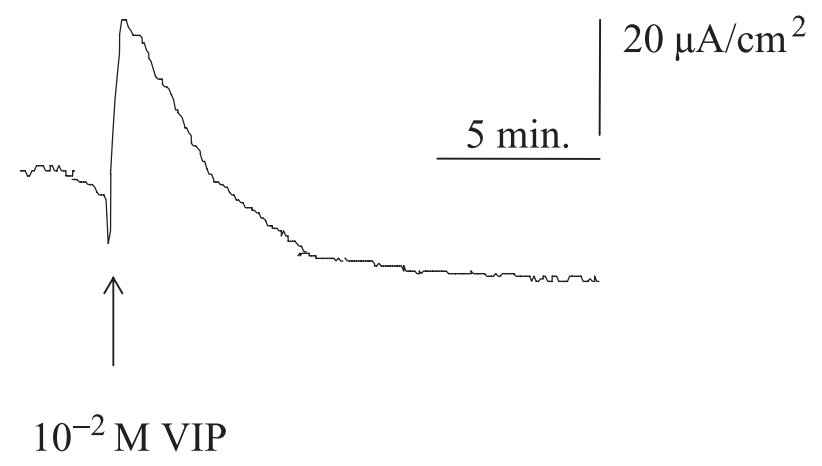

Figure 3. Example of response of the short-circuit current (Isc) to a secretagogue (Vasoactive Intestinal Peptide, VIP). The addition of VIP induces $\mathrm{Cl}^{-}$secretion from the enterocyte. The increase in the potential difference induced by this secretion is compensated by an increase of Isc to maintain the potential difference at $0 \mathrm{mV}$.

molecule probes [20] and macromolecules [23]. This can be done by simply adding the labeled compound in one side of the chamber and sampling the solution in the other side to determine the permeability of the tissue to this given compound.

Recently, the involvement of the enteric nervous system on interactions of pathogenic or commensal bacteria with epithelial cells was evaluated in Ussing chambers by adding bacteria into the mucosal reservoir, stimulating the enteric nervous system by pharmacological means and culturing the tissue taken from the chambers [36] to investigate the attachment and internalization of those bacteria into the tissue. This approach had already been used to investigate the difference in the transepithelial passage of bacteria between newborn and weanling piglets [37]. Ussing chambers have also been used to study the permeability of bovine and ovine intestine to another type of infectious agent, the hamster scrapie prion protein [29].

Lastly, Ussing chambers can be used to mimic pathophysiological situations. Epithelial injury can for example be mimicked by addition of detergents like Triton X-100 for a short amount of time [32]. Ischemia can also be modeled by replacing $\mathrm{O}_{2}$ by $\mathrm{N}_{2}$
[22]. Psychological stress can also be mimicked by adding into the chambers the neurotransmitters released after a stress like $\mathrm{CRH}$, norepinephrine or ACTH [36].

\subsection{Limits of the technique}

Ussing chambers suffer from all the drawbacks inherent to any in vitro technique: the excision of the tissue from the animal suppresses the action of any endocrine substance. For instance, the involvement of GLUT2 in glucose absorption at the brush border membrane level of the enterocyte has been overlooked for years since the trafficking of this transporter is under the influence of endogenous hormones that are absent in Ussing chambers [24]. In addition, all the central and autonomic nervous influences are suppressed. However, and as opposed to cell culture devices, the influence of part of the enteric nervous system as well as the local immune system is preserved.

Another limit of the technique is the viability of the tissue. The histological study of pig tissue fixed after $2 \mathrm{~h}$ in Ussing chambers showed an initial edema in all connective tissue as well as many desquamated cells at the luminal surface. The tight junctions, however, remained intact (Skadhauge et al., 
personal communication). A measure of the release of LDH (lactate dehydrogenase) during the $6 \mathrm{~h}$ following the mounting of human ileal mucosa in Ussing chambers show an increase in LDH release with time. However, the rate of $\mathrm{LDH}$ release, which was low at the beginning of the experiment, dramatically increases after $2 \mathrm{~h}$ of the experiment [38]. In practice, to minimize viability problems, experiments are usually limited in time ( 2 to $3 \mathrm{~h}$ after collection of the tissue), specific nutrients can be added to the buffer and measures of transport of glucose at the end of the experiment or recording of electrical parameters (Isc, PD or R) along the experiment are used to check tissue viability.

\section{THE USE OF USSING CHAMBERS TO STUDY INTESTINAL PHYSIOLOGY AT WEANING}

The knowledge of the events occurring in the digestive tract at weaning in piglets is useful to define the targets that the alternatives to antibiotics should be directed towards (flora, immune system, epithelium...). A study of intestinal physiology of weanling piglets therefore seems an essential step in order to find alternatives to antibiotics. Ussing chambers can be very useful in this regard.

\subsection{Disturbances of piglet intestinal physiology at weaning}

Only few reports investigated intestinal physiology of piglets at weaning using Ussing chambers. The first report was from Miller and Skadhauge [31] in 1997. They studied basal Isc and unidirectional $\mathrm{Na}$ and $\mathrm{Cl}$ fluxes of the ileum of piglets 7 days after weaning compared to unweaned piglets of the same age. They observed a lower basal Isc in the ileum of weaned piglets compared to unweaned piglets, irrespective of the diet. This decrease in Isc was mainly accounted for by a decrease in mucosal-to-serosal $\mathrm{Na}^{+}$ flux, with almost no change in $\mathrm{Cl}^{-}$fluxes [31]. Later, Spreeuwenberg et al. [40] investigated the effect of weaning on intes- tinal barrier function. They observed an increase of the paracellular passage of mannitol and transcellular absorption of GlySar two days after weaning, which were back to normal after seven days [40].

In an attempt to understand the changes in intestinal physiology occurring at weaning, our group recently investigated in Ussing chambers the absorptive and secretory physiology as well as the intestinal barrier function of the piglet proximal jejunum, ileum and colon during the 2 weeks following weaning [7]. To reduce the variability due to differences in food intake between piglets, the animals were tube-fed during 2 weeks. The animals were sacrificed the day of weaning (d0) then 2, 5, 8 and 15 days after weaning. The results indicate that weaning induces transient dramatic modifications of intestinal physiology as well as long lasting changes. For example, in the proximal small intestine, an increase of Isc together with a dramatic decrease of the transepithelial resistance were observed 2 days after weaning. These phenomena were acute since those parameters were back to preweaning values by day 5 . On the contrary, in the ileum, we observed long-lasting changes with the appearance of features characteristic of the adult distal intestine two weeks after weaning (Tab. I).

\subsection{Study of the direct effect of the different stress encountered by piglets at weaning}

Beside the study of the effect of weaning per se on intestinal physiology, pieces of information can be gathered from studies investigating the effect of the individual stress encountered at weaning by piglets (fasting, psychological stress, dietary switch...). Indeed, the effect of fasting has been investigated by mounting in Ussing chamber tissue from piglets fasted for $48 \mathrm{~h}$ compared to tissue from fed piglets $[10,20]$. The effect of psychological stress, both acute and chronic, has been largely investigated in vitro by placing the tissue of rats submitted to different stressors in Ussing chambers and 
Table I. Changes in intestinal physiology parameters, measured in Ussing chambers, induced by weaning in pigs.

\begin{tabular}{lcccccc}
\hline & \multicolumn{2}{c}{ jejunum } & \multicolumn{2}{c}{ ileum } & \multicolumn{2}{c}{ colon } \\
& $\mathrm{d} 2$ & $\mathrm{~d} 5-\mathrm{d} 15$ & $\mathrm{~d} 2$ & $\mathrm{~d} 5-\mathrm{d} 15$ & $\mathrm{~d} 2$ & $\mathrm{~d} 5-\mathrm{d} 15$ \\
\hline Isc & $\nearrow$ & - & - & - & $\nearrow$ & - \\
R & $\searrow$ & - & - & $\nearrow$ & - & - \\
HRP flux & $\searrow$ & $\searrow$ & - & - & - & - \\
5-HT & - & $\searrow$ & - & - & - & - \\
glucose & $\nearrow$ & $\searrow$ & $\searrow$ & $\searrow$ & nd & nd \\
\hline
\end{tabular}

Isc: short-circuit current, R: resistance of the tissue, HRP flux: flux of horseradish peroxidase, 5-HT: serotonin; nd: not determined.

The two weeks following weaning has been divided into two periods: the first 2 days (d2) where acute modifications of intestinal physiology are observed, mainly in the jejunum and the remaining of the period (d5-d15) where some more profound and long-lasting changes appear (adapted from [7]).

studying ion transport as well as epithelial barrier function [39]. Lastly, the effect of an abrupt dietary switch mimicking the one occurring at weaning has been investigated by maintaining piglets on artificial milk after weaning, switching them abruptly to a plant-based diet and studying intestinal physiology in Ussing chambers 4 days after the switch [5]. From all these studies, it appears that the individual stress encountered at weaning by piglets induces an increase in Isc, a higher response to secretagogues and for some of them a defect of the epithelial barrier function.

\section{USSING CHAMBERS TO STUDY THE EFFECT OF ALTERNATIVES TO IN-FEED ANTIBIOTICS APPLIED TO THE ANIMALS IN VIVO}

\subsection{Effect of diets}

Among practices liable to reduce postweaning diarrhea, the choice of a beneficial diet is usually the first one that comes to mind. The effect of two diets differing in their protein source (soybean-based versus egg-based) has been investigated by Miller and Skadhauge [31]. They did not find any difference between the two diets 7 days after weaning. Our group also studied two diets to assess dietary influence on gut disorders. One diet contained $60 \%$ of wheat whereas the other one contained mainly dairy products and barley. Similar to Miller and Skadhauge, we did not find any difference between the two diets for any of the parameters measured [7]. Likewise, Spreeuwenberg et al. [40] tested diets differing in lactose and protein ratio in their study of intestinal epithelial permeability during the 4 days following weaning. They observed a tendency to a decrease of paracellular permeability when piglets were offered a high lactose and low protein diet. The type of the diet seems therefore to have only a small influence on gut dysfunction at weaning.

\subsection{Effect of the physical form of the diet}

Another way often proposed to reduce post-weaning gastro-intestinal disturbances is to feed piglets with a liquid diet as opposed to a solid one. Verdonk et al. [42] compared intestinal paracellular permeability and peptide absorption capacities of piglets weaned on isocaloric diets offered in a solid or a liquid form to the piglets. They found a lower absorption of the peptide GlySar when piglets were fed a liquid diet, 
without any difference between diets for the paracellular permeability. Although the paracellular permeability was increased 2 days after weaning, as previously demonstrated by Spreeuwenberg et al. [40], there was no beneficial effect of the liquid diet over the solid one.

\subsection{Study of different additives}

The currently used alternatives to in-feed antibiotics are pro- and pre-biotics, supplementation of the diet with $\mathrm{Zn}$ or addition of organic acids. Only few studies have used Ussing chambers to evaluate the effect of these additives on intestinal physiology.

The effect of probiotics has been tested on epithelial cell monolayers mounted in Ussing chambers and exposed to Lactobacillus plantarum (LBP) before, after or simultaneously with enteropathogenic Escherichia coli, EPEC [30]. A similar study has been performed with rats offered LBP 7 days in the drinking water [27]. LBP had no direct effect on Isc of the epithelial cell monolayers, but was able to decrease by one third the response induced by EPEC when the monolayers were pre-incubated with LBP. The effect of the probiotic was mainly accounted for by a reduction of the attachment of EPEC to the cells rather than a direct effect on the secretory capacity of the enterocytes. In rats, LBP was able to reduce the increase in paracellular permeability induced by $E$. coli. The effect of another probiotic, Lactobacillus $G G$ (LGG), on the permeability of the small intestine of rat pups fed this probiotic by gavage for 7 days has also been investigated [35]. In rat pups, the addition of LGG to the diet reduced by 5 times the passage of intact horseradish peroxidase but modulated the degradation of this macromolecule, depending on the type of diets the rat pups were fed (intact versus hydrolyzed milk protein). The effect of the addition of Saccharomyces boulardii and Bacillus cereus in the diet during 3 weeks on nutrient absorption and basal electrical parameters of the small intestine was studied in grow- ing pigs. The addition of these probiotics to the diet was followed by an Isc response two-times bigger than the controls. Further investigations using brush border membrane vesicles have demonstrated an increase in Vmax for $\mathrm{Na}^{+}$-dependent glucose uptake [8]. Another recent study investigated the effect of Enterococcus faecium (Ef) on the intestinal physiology in piglets. Sow and piglets received the probiotic from birth to 56 days of age. The probiotic Ef induced an increase in the absorption of L-glutamine and glucose at 14 days of age as well as an increase in the paracellular permeability to mannitol. At 28 days of age, the probiotictreated piglets exhibited a higher response to the prostaglandin PGE2 [26]. The role of this probiotic in these circumstances does not seem very beneficial to the piglets (an increase in paracellular permeability, higher responses to PGE2) but this needs to be confirmed in other studies. Other strains of probiotics should also be considered.

The effect of prebiotics (topinambur powder or inactivated yeast) was investigated in growing pigs fed these prebiotics for 3 weeks. Basal or forskolin stimulated Isc was not altered by the prebiotics whereas tissue conductance tended to be higher in the prebiotic-fed animals. Topinambur increased mucosal-to-serosal fluxes of mannitol in the proximal and distal jejunum, which could only be demonstrated for the distal jejunum when inactivated yeasts were fed [9]. The effect of a yeast protease has also been investigated on human colonic biopsies mounted in Ussing chambers: a protease extracted from Saccharomyces boulardii was able to reverse the drop in transepithelial resistance induced by the toxins $A$ and B secreted by Clostridium difficile [12].

A recent study showed that zinc supplementation can enhance gastro-intestinal function at weaning [11]. The response to secretagogues (5-HT and cAMP-agonist) was decreased when the piglets were fed a diet enriched with $2500 \mathrm{mg} \cdot \mathrm{kg}^{-1}$ of Zn compared to $100 \mathrm{mg} \cdot \mathrm{kg}^{-1}$. However, the feed intake was higher in the $2500 \mathrm{mg} \cdot \mathrm{kg}^{-1}$ 
group, which might partly account for the differences observed.

\subsection{Limits}

Although the study of alternatives to infeed antibiotics by mounting the tissues of animals treated with those different alternatives in Ussing chambers seems to be the best approach, this type of experiment has its limits. Indeed, this approach needs many animals if different doses as well as different feeding times are to be tested. Moreover, and in order to specifically address the question of the effect of the alternatives alone, the sanitary conditions as well as the feed intake of the animals have to be well controlled.

A way to address this issue could be to test the effect of different alternatives, mainly plant extracts, on intestinal physiology by adding the substances directly into the chambers.

\section{THE USE OF USSING CHAMBERS TO STUDY THE IMMEDIATE EFFECTS OF SUBSTANCES ADDED INTO THE CHAMBERS}

\subsection{Principle}

The immediate action of different substances on intestinal physiology can be assessed in Ussing chambers. Indeed, the technology of the chambers allows bringing such substances into contact with the tissue for a short period of time, provided these substances are soluble. The effect of these substances on Isc, epithelial barrier function or responses to secretagogues can be measured immediately or after a short period of incubation. Dose-responses and timecourse curves can then be performed. Moreover a difference between mucosal and serosal application of the substance can be determined. Determination of the mechanisms involved can be assessed by using pharmacological approaches or by substituting ions in the media.

The substances tested are often plant extracts whose biological activity is suspected from empirical observations. Some can be detrimental to the tissue, inducing ion secretion or inhibiting glucose absorption. For instance the flavonol quercitin has been shown to induce $\mathrm{Cl}^{-}$and $\mathrm{HCO}_{3}^{-}$secretion in the rat colon in Ussing chambers [13]. Serosal peppermint oil decreases the secretory response to acetylcholine in the rat small intestine but when applied on the mucosal side, it inhibits $\mathrm{Na}^{+}$-dependent glucose absorption [3]. Similarly, our group recently demonstrated that soybean contains heat-sensitive substances able to inhibit $\mathrm{Na}^{+}-$ dependent glucose absorption and cAMPinduced $\mathrm{Cl}^{-}$secretion [6]. Some compounds also have a benefic effect on the intestine. A factor purified from boiled rice can block the secretory response to cAMP of intestinal T84 cells [28]. Genistein from soybean is able to augment the prostaglandininduced recovery of barrier function in the ischemia-injured ileum of pigs [4].

The direct effect of antibiotics on intestinal function can also be directly assessed by the addition of the antibiotics in the chambers. To our knowledge, this has been performed only in the rabbit, with only a few significant differences between the vehicle and antibiotic-treated tissue [18].

\subsection{Limits}

The main drawback of using Ussing chambers to test the effect of different substances is that the substances tested are not the ones that might be in contact with the mucosa in vivo, i.e. they have not been submitted to the hydrolysis from the gastrointestinal tract secretions. To our knowledge, no study has been performed with actual intestinal digesta extracts added into the chambers.

Other drawbacks are the choice of the incubation times, doses and kinetics of 
the addition of the substance. Moreover, the physical property of the substances (mainly solubility) can become an obstacle to the performance of such studies. The effect of the substances also has to be as short as possible since the viability of the tissue is limited in time in Ussing chambers.

To be completely valid, these in vitro experiments should be preceded by preliminary in vivo experiments to identify optimal conditions (dose, timing, metabolites, ...) or be followed by in vivo experiments confirming the actual effect of the substances.

\subsection{Studies combining in vitro and in vivo data}

Some studies have successfully investigated the effect of substances on intestinal physiology in Ussing chambers and related those results to in vivo data. For example, bromelain, a proteolytic extract from pineapple, has been shown to reduce the incidence of $\mathrm{K}^{2} 8^{+}$ETEC diarrhea in piglets [14]. The effect of this substance has been attributed to temporary inhibition of the $\mathrm{K}^{8} 8^{+}$ETEC receptor but also to an ability of this substance to prevent secretagogueinduced secretion (prostaglandin E2, theophylline, calcium-ionophore A23187, ...) in the rabbit ileum mounted in Ussing chambers [33]. Similarly, a substance derived from the latex of the plant Croton lechleri is able to significantly reduce the fluid accumulation induced by cholera toxin in mice small intestine in vivo. The effect of the substance was confirmed in Ussing chambers on Caco-2 and T84 monolayers: the extract was able to dose-dependently inhibit Isc as well as cAMP-mediated secretion [17]. Besides pathogen-induced secretion, pathophysiological conditions have also been investigated. The increase in Isc observed in the rat intestine after psychological stress was inhibited by seirogan (wood creosote) added in Ussing chambers. When administered by oral gavage, this substance was able to normalize Isc to control levels [2].
If, in most of the publications, the in vivo data match the in vitro ones, there are also some reports where in vivo experiments give results opposite to the in vitro ones. For example, oat saponins are able to increase rat intestinal permeability to ${ }^{14} \mathrm{C}$-mannitol and ${ }^{51} \mathrm{Cr}$-EDTA in Ussing chambers. However, when administered orally, the passage of ${ }^{51} \mathrm{Cr}$-EDTA into the blood and urine tends to be reduced [34].

A combination of Ussing data with other measures of intestinal physiology (enzymatic activities, number of immune cells, cytokine expression...) and structure can be useful for the understanding of the physiopathology of intestinal disorders at weaning. For example, our group was able to demonstrate that the switch from milkbased to cereal-based diets such as what happens at weaning induces functional changes but no structural damages [5]. Correlations between parameters can also be performed. Spreeuwenberg et al. [40] demonstrated positive correlations between para- and trans-cellular permeability measured in Ussing chambers and the number of $\mathrm{CD}^{+} \mathrm{T}$ cells present in the intestine after weaning.

\section{CONCLUSION}

The necessity of finding alternatives to in-feed antibiotics in animal production has brought scientists to use different techniques to evaluate those alternatives. We believe that the Ussing chamber can be one of these techniques. It allows a direct measurement of the phenomena at the mucosal level, both when studying tissues from piglets treated with these alternatives or by directly exposing the tissues to the substances tested. Moreover, this technique allows, at least partly, the elucidation of the mechanisms of action of those alternatives. However, it must be kept in mind that largescale trials should also be performed to validate the usefulness of those alternatives in vivo. 


\section{REFERENCES}

[1] Alexander A.N., Carey H.V., Oral IGF-I enhances nutrient and electrolyte absorption in neonatal piglet intestine, Am. J. Physiol. 277 (1999) G619-625.

[2] Ataka K., Kuge T., Venkova K., GreenwoodVan Meerveld B., Seirogan (wood croseote) inhibits stress-induced ion secretion in rat intestinal epithelium, Dig. Dis. Sci. 48 (2003) 1303-1309.

[3] Beesley A., Hardcastle J., Hardcastle P.T., Taylor C.J., Influence of peppermint oil on absorptive and secretory processes in rat small intestine, Gut 39 (1996) 214-219.

[4] Blikslager A.T., Roberts M.C., Young K.M., Rhoads J.M., Argenzio R.A., Genistein augments prostaglandin-induced recovery of barrier function in ischemia-injured porcine ileum, Am. J. Physiol. 278 (2000) G207-216.

[5] Boudry G., Lallès J.P., Malbert C.H., Bobillier E., Sève B., Diet-related adaptation of the small intestine at weaning in pigs is functional rather than structural, J. Pediatr. Gastroenterol. Nutr. 34 (2002) 180-187.

[6] Boudry G., Lallès J.P., Malbert C.H., Grondahl M.L., Unmack M.A., Skadhauge E., Soybean impairs $\mathrm{Na}^{+}$dependent glucose absorption and $\mathrm{Cl}^{-}$secretion porcine small intestine, Rep. Nutr. Dev. 43 (2003) 409-418.

[7] Boudry G., Péron V., Le Houerou-Luron I., Lallès J.P., Sève B., Weaning induces both transient and long-lasting modifications of absorptive, secretory and barrier properties of piglet intestine, J. Nutr. (2005) in press.

[8] Breves G., Walter C., Burnmester M., Schroder B., In vitro studies on the effects of Saccharomyces boulardii and Bacillus cereus var. toyoi on nutrient transport in pig jejunum, J. Anim. Physiol. An. N. 84 (2000) 9-20.

[9] Breves G., Szentkuti L., Schroder B., Effects of oligosaccharides on functional parameters of the intestinal tract of growing pigs, Dtsch. Tierarztl. Wochenschr. 108 (2001) 246-248.

[10] Carey H.V., Hayden U.L., Tucker K.E., Fasting alters basal and stimulated ion transport in piglet jejunum, Am. J. Physiol. 267 (1994) R156-163.

[11] Carlson D., Poulsen H.D., Sehested J., Influence of weaning and effect of post weaning dietary zinc and copper on electrophysiological responses to glucose, theophylline and 5HT in piglet small intestinal mucosa, Comp. Biochem. Physiol. A Mol. Integr. Physiol. 137 (2004) 757-765.

[12] Castagliuolo I., Riegler M.F., Valenick L., LaMont J.T., Pothoulakis C., Saccharomyces boulardii protease inhibits the effects of Clostridium difficile toxins $\mathrm{A}$ and $\mathrm{B}$ in human colonic mucosa, Infect. Immun. 67 (1999) 302-307.

[13] Cermak R., Föllmer U., Wolffram S., Dietary flavonol quercitin induces chloride secretion in rat colon, Am. J. Physiol. 275 (1998) G1166-1172.

[14] Chandler D.S., Mynott T.L., Bromelain protects piglets from diarrhoea cause by oral challenge with K88 positive enterotoxigenic Escherichia coli, Gut 43 (1998) 196-202.

[15] Chang E.B., Rao M.C., Intestinal water and electrolyte transport, in: Johnson L.R. (Ed.), Physiology of the gastrointestinal tract, Raven Press, New York, USA, 1994, pp. 2027-2082.

[16] Erlwanger K.H., Unmack M.A., Grondahl M.L., Skadhauge E., Thorboll J.E., Effect of age on vasoactive intestinal polypeptideinduced short-circuit current in porcine jejunum, Comp. Biochem. Physiol. A 124 (1999) 29-33.

[17] Gabriel S.E., Davenport S.E., Steagall R.J., Vimal V., Carlson T., Rozhon E.J., A novel plant-derived inhibitor of cAMP-mediated fluid and chloride secretion, Am. J. Physiol. 276 (1999) G58-63.

[18] Goldhill J.M., Rose K., Percy W.H., Effects of antibiotics on epithelial ion transport in the rabbit distal colon in vitro, J. Pharm. Pharmacol. 48 (1996) 651-656.

[19] Grondahl M.L., Munck L.K., Skadhauge E., Regional differences in the effect of mucosal glucose and amino acids on ion transport in normal and cholera toxin-stimulated porcine small intestine, Scand. J. Gastroenterol. 32 (1997) 478-484.

[20] Hayden U.L., Carey H.V., Neural control of intestinal ion transport and paracellular permeability is altered by nutritional status, Am. J. Physiol. 278 (2000) R1589-1594.

[21] Holtug K., Hansen M.B., Skadhauge E., Experimental studies of intestinal ion and water transport, Scand. J. Gastroenterol. 31 (Suppl. 216) (1996) 95-110.

[22] Inauen W., Payne D.K., Kvietys P.R., Granger D.N., Hypoxia/reoxygenation increases the permeability of endothelial cell monolayers: role of oxygen radicals, Free Radic. Biol. Med. 9 (2000) 219-223.

[23] Keljo D.J., Hamilton J.R., Quantitative determination of macromolecular transport rate across intestinal Peyer's patches, Am. J. Physiol. 244 (1983) G637-644.

[24] Kellett G.L., The facilitated component of intestinal glucose absorption, J. Physiol. 531 (2001) 585-595. 
[25] Lampen A., Zhang Y., Hackbarth I., Beneth L.Z., Sewing K.F., Christians U., Metabolism and transport of the macrolide immunosuppressant sirolimus in the small intestine, J. Pharmacol. Exp. Ther. 285 (1998) 1104-1112.

[26] Lodemann U., Huebener K., Jansen N., Martens H., Effects of an Enterococcus faecium probiotic in pigs: effect on barrier function and transport properties of pig jejunum, Anim. Res. 53 (2004) 335.

[27] Mangell P., Nejdfors P., Wang M., Ahrne S., Westrom B., Thorlacius H., Jeppson B., Lactobacillus plantarum 299v inhibits Escherichia coli-induced intestinal permeability, Dig. Dis. Sci. 47 (2002) 511-516.

[28] Matthews C.J., MacLeod J., Zheng S.X., Hanrahan J.W., Bennett H.P., Hamilton J.R., Characterization of the inhibitory effect of boiled rice on intestinal chloride secretion in guinea pig crypt cells, Gastroenterology 116 (1999) 1342-1347.

[29] McKie A.T., Zammit P.S., Naftalin R.J., Comparison of cattle and sheep colonic permeabilities to horseradish peroxidase and hamster scrapie prion protein in vitro, Gut 45 (1999) 879-888.

[30] Michail S., Abernathy F., Lactobacillus plantarum reduces the in vitro secretory response of intestinal epithelial cells to enteropathogenic Escherichia coli, J. Pediatr. Gastroenterol. Nutr. 35 (2002) 350-355.

[31] Miller B.G., Skadhauge E., Effect of weaning in the pig on ileal ion transport measured in vitro, J. Vet. Med. 44 (1997) 289-299.

[32] Moore R., Carlson S., Madara J.L., Rapid barrier restitution in an in vitro model of intestinal epithelial injury, Lab. Invest. 60 (1989) 237 244.

[33] Mynott T.L., Guandalini S., Raimondi F., Fasano A., Bromelain prevents secretion caused by Vibrio cholerae and Escherichia coli enterotoxins in rabbit ileum in vitro, Gastroenterology 113 (1997) 175-184.
[34] Onning G., Wang Q., Westrom B.R., Asp N.G., Karlsson B.W., Influence of oat saponins on intestinal permeability in vitro and in vivo in the rat, Brit. J. Nutr. 76(1996) 141-151.

[35] Pessi T., Sütas Y., Marttinen A., Isolauri E., Probiotics reinforce mucosal degradation of antigens in rats: implications for therapeutic use of probiotics, J. Nutr. 128 (1998) 2313-2318.

[36] Schreiber K., Brown D.R., Enteric nervous system modulation of mucosal-pathogen interactions in porcine intestine, Neurogastrol. Motil. 15 (2003) 232.

[37] Smith S.D., Cardona M.A., Wishnev S.A., Kurkchubasche A.G., Rowe M.I., Unique characteristics of the neonatal intestinal mucosal barrier, J. Pediatr. Surg. 27 (1992) 333-338.

[38] Söderholm J.D., Hedman L., Artursson P., Franzén L., Larsson J., Pantzar N., Permert J., Olaison G., Integrity and metabolism of human ileal mucosa in vitro in the Ussing chamber, Acta Physiol. Scand. 162 (1998) 47-56.

[39] Söderholm J.D., Perdue M.H., Stress and gastrointestinal tract II: Stress and intestinal barrier function, Am. J. Physiol. 280 (2001) G7-13.

[40] Spreeuwenberg M.A., Verdonk J.M., Gaskins H.R., Verstegen M.W., Small intestine epithelial barrier function is compromised in pigs with low feed intake at weaning, J. Nutr. 131 (2001) 1520-1527.

[41] Ussing H.H., Zerahn K., Active transport of sodium as the source of electric current in the short-circuited frog skin, Acta Physiol. Scand. 19 (1951) 43-56.

[42] Verdonk J.M.A.J., Vente-Spreeuwenberg M.A.M., Mroz Z., In vitro permeability and histo-immunological changes in the small intestine of weaned piglets fed isoenergetic rations in liquid or dry forms, Anim. Res. 54 (2005) in press. 